\title{
Work Life Balance and Commitment of Government Hospital Nurses
}

\author{
K. H. M. K. Dayananda ${ }^{1}$ and S. M. A. K. Samarakoon ${ }^{2}$ \\ ${ }^{1}$ Postgraduate Student, Master of Commerce, Department of Commerce and Financial \\ Management, University of Kelaniya, Sri Lanka \\ ${ }^{2}$ Senior Lecturer, Department of Commerce and Financial Management, University of \\ Kelaniya, Sri Lanka \\ ${ }^{1}$ rgunasekara@gmail.com, ${ }^{2}$ samarakoonak@kln.ac.lk
}

\begin{abstract}
The nurses play a crucial role in the government hospital and their commitment and the work life balance seem to have a greater impact to make ensure quality of health sector in the country. The main emphases of the study are to figure out the factors affect to the Work Life Balance (WLB) on government hospital nurses in Sri Lanka and to analysis the Work Life Balance influence on job Commitment among government hospital nurses. The study conducted using primary data gathered focusing government hospitals in Colombo area. Participants are asked to complete structural questionnaires, which were developed to measure demographic factors and research variables. Questionnaires distributed among nurses working in the selected three hospitals in Colombo district. Hundred and five competed questionnaires returned from respondents. Hundred competed questionnaires were used to final data analysis. Descriptive statistics and correlation analysis and regression were utilized to data analysis.
\end{abstract}

The study assessed the effect of four independent variables on the Work Life Balance and it was found the working environment, work stress, financial encouragement and Job Autonomy have greater impact to the work life balance. It was found that the working environment, work stress, financial encouragement and Job Autonomy has greater impact to the Work Life Balance. Public sector still plays a vibrant role in every country. If public sector employees are not satisfied with their motives, employee performance will deteriorate and inefficiency will be increased. It may also be a part of grievances, low productivity, disciplinary problems and other organization difficulties. Moreover, it is noted that Work life balance and working commitment have strong positive relationship. In this context, it can be concluded that the proper WLB will lead to high working commitment in nursing professionals. Further higher WLB leads to enhance the quality of health service in the country.

Keywords: Work life balance, Organizational commitment, Job autonomy, Work stress, Working environment, Nurses

\section{Background of the Study}

In the modern world, importance of Work Life Balance (WLB) has been incitingly enhanced in the world as it ultimately heads towards measuring quality of life of people in any society. Further, over the recent decades, global demographic changes such as an enlarged participation of women in the 
labor force, two-income households, single-parent families and eldercare have resulted in increased challenges faced by workers who tried to balance demands of work and family life (Tennant\& Sperry, 2003; Young, 1999). Further, Work life balance considered as a major factor in an organization as employees being deviated from their group goals towards the organization. Work Life Balance contains creating and maintaining favorable working environment in an organization which employees will enable to have balance work and personal responsibilities and as a result of that commitment of employees will enhance then and finally it will have benefitted to loyalty and productivity of organization. Both internal and external factors affect them in achieving combined goal accomplishment. And this is very concern in society and organization about the impact of multiple roles on the health and well-being of professional women and its implications regarding work and family performance and women's role in society (Balaji, 2014). Further, Allen, (2006) mentioned that MLB is able to explain as those practices at their workplace that appreciate and support the wants of workers in accomplishing a sense of balance between the demands of their work and life. The Work Life Balance is a dynamic phenomenon and it is also an individual based by nature, although there are several common issues across different types of people.

The empirical analysis suggests that proper measures on WLB enable to achieve both individual and organizational goals optimally. On the other hand, Work Life Balance is a people centric measurement as the responsibility of any work is to ensure the wellbeing of the society as a whole but not focuses only targeted segment of the entire world. The work related literature suggests that working conditions are becoming increasingly stressful (Judge \& Colquitt, 2004) due to the complexity of the modern society. The some one can argue that the existing complex economic structures may have direct impact to maintain poor WLB, which results to declining the quality of overall life style of the people experienced in developing counties.

The job of healthcare workers is undoubtedly very challenging and demanding in the today's context. Amon the healthcare workers, the role of nurses in the health care system is expanding and changing as proper care is much more important for mental recovery of patients. As such, their role is not just limited to institutional care but also involves delivery of services at various levels of the health care system. The scope of the job of nurses inherently linked to stressfulness, quick response, criticism from patients and relatives, more responsible etc. Further, they frequently experience heavy workload, emotional stress as they are always being together with painful patients, working with deathly patients, conflicts with the patients and their relatives, night and long working conditions, which belong to nurses' working environment, lead them to burn out, be insensitive and quit their jobs. While working for long and inconsistent hours has physiologic, psychological and sociological effects on nurses, several studies revealed that 
it also has many negative impacts on the individual who receives the service Ayfun and Catir (2014). Further, Nurses' work life balance is found to influence the hospital performance and productivity (Suguna and Franco 2017). Since, in this context proper WLB in nursing profession is crucial in terms of ensuring quality of health care in general and particularly to enhance the quality of life of nurses.

Nurses are engaging government sectors as well as private sector within the Sri Lanka and government sector nurses are employed in government hospitals with government designated compensation schemes, with standard salary scales, leave policy, facilities and benefits as per the government regulations. As the government policy applied for every personnel work in the government sector, there are many issues affected to the commitment of employees with references to work life balance of all these governments employed nurses. In determining the link between work-life balance and commitment, Beauregard and Henry (2009) argue that commitment to work depends largely on the extent to which employees are able to balance work activities and non- work activities and are satisfied with the job they do and the conditions of service within which they work (Ampem 2018). In this context, selecting the nursing profession for this sturdy is most relevant to get proper understanding about the work and family life balance.

\section{Statement of the Problem}

Healthcare workers are considered to be the image builders for the hospitals irrespective of their positions i.e. doctors, nurses and other supporting staff. Health care workers are especially espouse to such conflicting situation in life as they are highly demanded and most important segment of work force. Azeem and Nadeem (2014) found that work life conflict as a major contributing factor to work stress of healthcare employees. Due to shift work, emergency care, shortage of staff and increased work demand, health care workers are facing worklife conflict quite often (Bryson et al., 2007; Fereday \& Oster, 2010).

Among the healthcare workers' nurses are performing a vital role in the Sri Lankan healthcare system in the both government and private hospitals. They play important role in caring for patients, preventing illness and assisting in improving in Sri Lakan health status of the country (De Silva and Rolls, 2010). Moreover, Suresh (2013) mentioned that the nurses are one of the strongest pillars of the health care delivery system in providing safe, affordable and quality services to the people. Therefore, nurses' commitment and the work life balance seem to have a greater impact in order to ensure quality of health sector in the country. However, researchers mentioned that many research on WLB conducted in Western contexts (Cohen $\&$ Kirchmeyer, 2005). Review of literature also observed that the there is a clear empirical gap, on understanding factors influence on work life-balance and its influence on job commitment among the government hospital nurses in Sri Lanka.

\section{Objectives of the Study}

- To analysis the factors, influence on work life balance of government hospital nurses in Sri Lanka. 
- To examine impact of work life balance on job commitment of government hospital nurses in Sri Lanka.

\section{Literature Review}

\section{Work Life Balance}

Greenbatt (2002) stated that WLB is the maintaining the non-occurrence of conflicts between work and nonworking demands. Some authors mentioned that WLB is to which extent that individual engages in work environment and family environment (Ex. Greenhaus, 2003). Both groups stated that sense of balance their work environment and family environment as the WLB. Moreover, Clark (2001) defined work life balance as "satisfaction and good functioning at work and at home with a minimum of role conflict" (p.349). This definition described deals with balance participation in paid work (defined by hours \& working conditions) and other aspects of lives. If there is imbalance in those work and life responsibilities which may lead to work life imbalance (Greenhaus, 2003). The work life imbalance ultimately affect both the quality of service provided and the lifestyle as well. Some researchers defined WLB as the maintaining the non-occurrence of conflicts between work and non-working demands (Ex. Greenbatt, 2002) and another group of researchers identified as which extent that individual engages in work environment and family environment (Ex. Greenhaus,2003). On the other hand, number of researches have been conducted to understand of the WLB of the different job categories (Carlson, Kacmar, Grzywacz, Tepper, \& Whitten, 2013).
Many researchers paid attention to the outcome of WLB such as employee commitment, employee satisfaction, employee retention etc.

\section{Work life balance and employee commitment}

Azeem and Nadeem (2014) found that work life conflict as a major contributing factor to work stress of healthcare employees. Further, due to shift work, emergency care, shortage of staff and increased work demand, health care workers are facing worklife conflict quite often (Bryson et al., 2007; Fereday\& Oster, 2010). It has also been empirically proven that the employee commitment has a positive correlation with the success of any organization. If there is imbalance in those work and life responsibilities which may lead to work life imbalance. (Greenhaus, 2003) The work life imbalance ultimately affect both the quality of service provided and the lifestyle as well. Work-life balance, which primarily deals with an employees' ability to properly prioritize between work and his or her personal lifestyle, social life, health, family etc., is greatly linked with employee commitment, productivity, performance and job satisfaction (Rathnayaka 2015). WLB is especially important when organization has to manage highly technical professionals because their high commitment and loyalty is needed for the success of the organization (Scholarios \& Marks, 2006). In case of hospital employees, work-life balance and their commitment influence the performance and productivity of the hospital (Sakthivel \& Kamalanabhan, 2011; Sakthivel \& Jayakrishnan, 2012). 


\section{Factors influence on Work Life Balance}

As per the lot of empirical findings, the work life balance depends of key factors including work life conflict (family to work interference, work to family interference), stress (work related, family related), workload, job autonomy etc.

\section{- Work Stress}

The working stress may have broad and adverse implications for employee health; chronic stress can alter an individual's immune system, cause inflammation, higher blood pressure, hypertension and other cardiovascular issues (Kang, et al., 2010). Such conditions are inconsistent with a productive and satisfied workforce. Indeed, one of the most common reasons for employee turnover is stress (Porter \&Alman, 2010). In this background, as worldwide experienced if a particular employee unable to balance his personal life with the workload it may lead to working stress and might be end up with health issues, which will hinder the achievement of organizational as well as individual goals. The work-life balance must be maintained effectively to make ensure that all employees are running at their peak potential and free from stress and strain (Nguru \& Gichuhi 2018).

\section{- Working Environment}

Working environment consists of safety to employees, job security, good relations with co-workers, recognition for good performance, motivation for performing well and participation in the decision making process of the firm. Once employees realize that the firm considers them important, they will have high level of commitment and a sense of ownership for their organization (Raziq \& Maulabakhsh, 2014). The wellbeing of workers who kept their employment can be negatively affected by job insecurity (Scherer, 2009). Many individuals feel under pressure to work longer hours to keep their jobs (Wayman, 2010), and to meet their family expenses (Edwards \& Rothbard, 2000). Some studies recognized that the main causes of poor WLB among the employees are excessive working hours and a lack of work schedule flexibility. Further family-friendly policies such as parttime work, flexi-time, flexiplace/teleworking, job-sharing, work sharing, term-time working, maternity leave, parental leave and adoptive leave lead to develop favorable working environment (Fisher, 2000).

\section{- Financial Rewards}

Work satisfaction can be divided into affective work satisfaction based on individuals' overall feeling about their job as a whole; and cognitive work satisfaction based on individuals' logical evaluation of the job conditions (e.g. working hours, pay and pension plans), opportunities and outcomes (Spector, 1997). According to Clark and Farmer (1998), work satisfaction refers to a sense of achievement and income stability. Firms deal with these tough economic times by cutting expenditure, decreasing staff levels and increasing workload for the remaining employees (O’Connell, Russell, Watson \& Byrne, 2010). Some organizations in the private sector offer WLB initiatives that do not directly affect the number of hours worked. 
These initiatives include: employee counselling, provision of financial advisors, financial support in employee education and medical facilities. Lakshmi and Gopinath (2013) stated that there was a significant relationship between marital statuses of women workers and overtime work. Married women workers with children and dependents primarily work for financial reasons and accept overtime work which severely damages their work - life balance.

\section{- Job Autonomy}

Research conducted by Clark (2000) found that workplace flexibility has a positive impact on employees' wellbeing and finally it leads to proper WLB. Employees with flexible work schedules achieve better WLB, which results in higher job satisfaction, higher home activity satisfaction, and lower role conflict.

As an effective route to attain work-life balance, Clark (2000) emphasized the availability of flexible workplace policies that support employee's autonomy. Clark has dissected the concept of "family friendly" to distinguish between practices associated with temporal flexibility, which gives workers some autonomy of when they work, and operational flexibility, which allows for autonomy of the content of work and supportive supervision and allows for rules to be flexible in the case of a family crisis, illness, and so forth.

The major findings were that workplace policies such as workschedule flexibility reduced negative spillover, especially for women. Moreover, Downes and Koekemoer
(2011) reported that employees felt that the use of flexible time for work gave them the psychological benefit of experiencing less stress and anxiety. Improved work - life balance made them feel relaxed, happy and enhanced their energy level at the workplace. It also gave them autonomy to schedule their work at their own pace which increased their productivity.

\section{Conceptual Framework and Hypothesis}

Base on the literature review and discussion with expert in the Human Resource Management field, the study has selected four factors that may influence on work - life balance policies. Job Autonomy, work stress, financial encouragement and working environment influence on work life balance were identified as independent variables. Second part of the model shows the influence of work life balance on employee commitment. Figure 01 shows the conceptual framework of the study. 


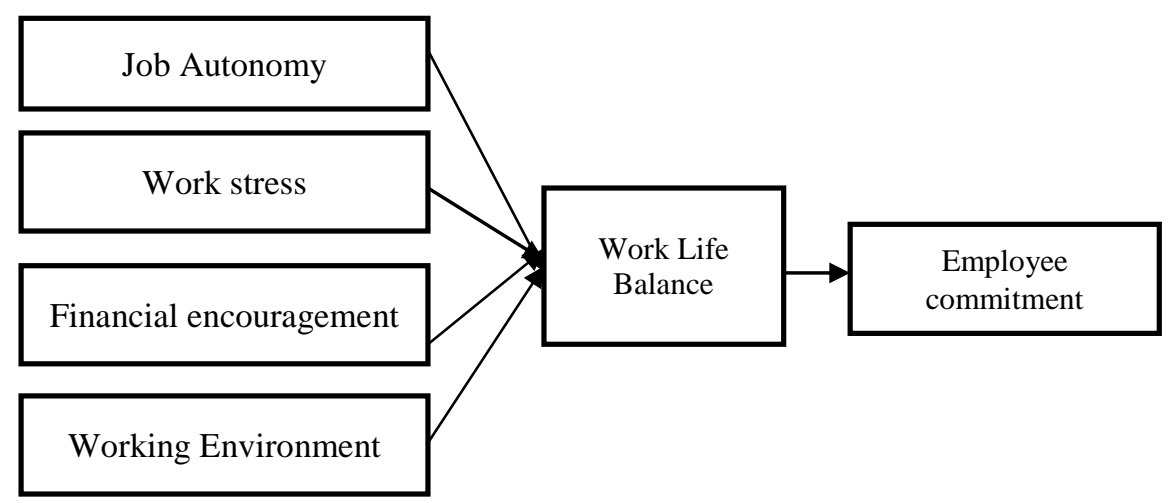

Figure 01: Conceptual Framework

Source: Authors, 2019

Many researchers' identified (e.g. Sakthivel \& Jayakrishnan, 2012) influence of work-life balance on employee commitment. Therefore, the author assumes that

$\mathbf{H}_{1}$ : Work-life balance positively influences on government hospital nurses' commitment in Sri Lanka.

\section{Research Methodology}

The research methodology was developed dragonizing available empirical studies with an aim to reach the set objectives. The more accessible Colombo centric three hospitals i.e. Colombo East Base Hospital, Colombo National Hospital and National Institute of Infectious Diseases Hospital (Fever Hospital) were selected in order to gather the primary data under the simple random sampling. The 145 questionnaires were distributed among the nurses in the three government hospitals in Colombo District. The sampling method used was simple random sampling.
A comprehensive questionnaire was used to explore the work life balance influencing factors, Work Life Balance and employee commitment. The questionnaire developed with 3 parts namely Part I, Part II and Part III. Part I developed for measure demographic factors to assess the respondent's demographic details, qualifications and service details. Part II included questions related to Work Life Balance and factors influence on work life balance. Final part of the questionnaire included questions related to assessment of employees' Commitment. Work-life balance, factors influence on work life balance and employee commitment were assessed by five-point Likert scale adopting standard questionnaires taken from literature. Researcher has conducted a pilot study in order to check the reliability of the selected variables. In order to analyze the model and test hypothesizes multiple regression and correlation analysis were performed. 


\section{Analysis and Results}

Hundred and five questionnaires were retrieved representing about 84 percent response rate. Hundred competed questionnaires were used to data analysis.

\section{Demographic Characteristics}

The following table describes the demographic dispersion among the selected nurses in the sample.

Table 01: Summary of Demographic Information

\begin{tabular}{|l|l|}
\hline Gender & Total \\
\hline Male & 19 \\
\hline Female & 81 \\
\hline Age & \\
\hline Less than 30 & 39 \\
\hline $31-40$ & 42 \\
\hline $41-50$ & 14 \\
\hline $51-60$ & 05 \\
\hline Service & \\
\hline Less than 05 & 40 \\
\hline 5 -10 years & 26 \\
\hline More than 10 & 34 \\
\hline Marital status & \\
\hline Married & 63 \\
\hline Unmarried & 37 \\
\hline Education qualification & \\
\hline Post graduate & 1 \\
\hline Degree & 16 \\
\hline Diploma & 83 \\
\hline $\begin{array}{l}\text { Average working hours } \\
\text { per week }\end{array}$ & \\
\hline Less than 50 & 16 \\
\hline 50 to 100 & 82 \\
\hline More than 100 & 02 \\
\hline Source: Survey Statistics \\
\hline
\end{tabular}

Source: Survey Statistics

Table 01 shows that the women participation in the nursing profession is significantly high having an 81 percent representation in the sample selected. The women in the Asian culture inherently represent majority of family work load in day to day life and as such the better work life balance among women nurses will seriously affect to the both personal life and the quality of the health service. The majority nurses working in government hospital married represented through marriage rate of 63 percent. In terms of the educational qualifications, only 17 percent of nurses in the government sector have degree or higher-level education and the others have compulsory diploma certificate. This seems to be one of the major bottleneck to the making the nursing profession more demanded. Regarding the working hours of nurses, 82 percent of nurses are engaging office work from 50 hours to 100 hours per week scarifying personal life. Researcher examine reliability values of each variables and the Cronbach's alpha coefficient values of independent and dependent variables are higher than 0.7.

Table 02: Descriptive Statistics for All Variables $(\mathbf{N}=100)$

Standard

\begin{tabular}{lcc} 
Variable & Mean & Deviation \\
\hline $\begin{array}{l}\text { Organizational } \\
\text { and } \\
\begin{array}{l}\text { Physiological } \\
\text { factors }\end{array}\end{array}$ & & \\
\hline Work Stress & 4.27 & 0.52 \\
\hline Job autonomy & 4.87 & 0.31 \\
\hline $\begin{array}{l}\text { Financial } \\
\text { encouragement }\end{array}$ & 3.85 & 0.14 \\
\hline $\begin{array}{l}\text { Working } \\
\text { Environment }\end{array}$ & 4.82 & 0.51 \\
\hline $\begin{array}{l}\text { Work-life } \\
\text { balance }\end{array}$ & $\mathbf{4 . 1 2}$ & $\mathbf{0 . 5 6}$ \\
\hline
\end{tabular}

Source: Survey Statistics 
According to the descriptive statistics, it shows that the highest mean value among the independent variable, which influence the work life balance, is on working environment. The working environment also has moderated standard deviation as well. The financial encouragement having mean and standard deviation of 3.85 and 0.14 respectively has shown a lowest contributor to the work life balance among the nursing profession. The average mean score of work life balance and its standard deviation are around 4.12 and 0.56 respectively. First objective of the study is to analysis the factors influence on work life balance of government hospital nurses in Sri Lanka. Researcher selected four independent factors namely job autonomy, financial encouragement, work stress and working environment. Table number 03 shows regression output of four independent factors influence on work life balance of nurses.

\section{Table 03: Multiple Regression Outputs}

\begin{tabular}{lr}
\hline \multicolumn{2}{c}{ Regression Statistics } \\
\hline Multiple R & 0.797404964 \\
R Square & 0.635854676 \\
Adjusted R Square & 0.620522242 \\
Standard Erro1 & 0.866127992 \\
Observations & 100 \\
\hline
\end{tabular}

\begin{tabular}{|c|c|c|c|c|c|}
\hline & $d f$ & $S S$ & $M S$ & $F$ & Significance $F$ \\
\hline Regression & 4 & 124.4431187 & 31.11077968 & 41.47121379 & 4.51594E-20 \\
\hline Residual & 95 & 71.26688128 & 0.750177698 & & \\
\hline Total & 99 & 195.71 & & & \\
\hline
\end{tabular}

\begin{tabular}{|c|c|c|c|c|c|c|c|c|}
\hline & Coefficients & Standard Error & $t$ Stat & P-value & Lower $95 \%$ & Upper 95\% & Lower $95.0 \%$ & Upper $95.0 \%$ \\
\hline Intercept & -0.605656685 & 0.434397458 & -1.394245463 & 0.166495794 & -1.468044676 & 0.256731305 & -1.468044676 & 0.256731305 \\
\hline Job Autonomy & 0.022939108 & 0.007263721 & 3.158038272 & 0.002129625 & 0.008518799 & 0.037359417 & 0.008518799 & 0.037359417 \\
\hline Work Stress & 0.036786744 & 0.014399146 & 2.554786464 & 0.012214014 & 0.008200824 & 0.065372664 & 0.008200824 & 0.065372664 \\
\hline Financial encouragement & 0.055315447 & 0.027233653 & 2.031143116 & 0.045034393 & 0.00124981 & 0.109381083 & 0.00124981 & 0.109381083 \\
\hline Working Environment & 0.05569367 & 0.012305079 & 4.526071852 & $1.74006 \mathrm{E}-05$ & 0.031265 & 0.080122339 & 0.031265 & 0.080122339 \\
\hline
\end{tabular}

Source: Survey Statistics

Table 03 shows the multiple regression output and it indicates that Job Autonomy, work stress, financial encouragement and working environment influence on work life balance of nurses working in the Colombo district.

Following regression equation can be derived for in this context;

Work life Balance $=-0.6057+$ $0.0229 X 1+0.0368 X 2+0.0553 X 3+0.0557$ $X 4+$ Standard Error
Where, X1-Job Autonomy, X2 - Work Stress, X3 - Financial Encouragement, X4 - Working Environment

This model seems to be statistical significant as the multiple regression coefficient and $\mathrm{R}$ square are 0.797 and0.6358 (63.58\%) respectively. Further, the most correlated independent variable for the WLB is working environment (coefficient value is 0.0557). It is observed that the output of the statistical regression is in line with 
the Hawthorne findings as the considered working environment were among the key factors as which included human relations instead of other dimensions. Moreover, other three factors namely job Autonomy, work stress and financial encouragement also significantly influence on Work-Life balance of nurses. To assess the impact of work life balance on job commitment of government hospital nurses in Sri Lanka.

\section{Table 04: Work Life Balance influence and job commitment of government hospital nurses in Sri Lanka}

SUMMARY OUTPUT

\begin{tabular}{lr}
\hline \multicolumn{2}{c}{ Regression Statistics } \\
\hline Multiple R & 0.778336131 \\
RSquare & 0.605807133 \\
Adjusted R Square & 0.601784756 \\
Standard Error & 0.732004618 \\
Observations & 100 \\
\hline
\end{tabular}

ANOVA

\begin{tabular}{|c|c|c|c|c|c|}
\hline & $d f$ & SS & MS & $F$ & Significance $F$ \\
\hline Regression & 1 & 80.70107845 & 80.70107845 & 150.6092674 & $1.58854 E-21$ \\
\hline Residual & 98 & 52.51141462 & 0.535830761 & & \\
\hline Total & 99 & 133.2124931 & & & \\
\hline
\end{tabular}

\begin{tabular}{lcccccccc}
\hline & Coefficients & Standard Error & tStat & P-value & Lower 95\% & Upper 95\% & Lower 95.0\% & Upper 95.0\% \\
\hline Intercept & 0.411799243 & 0.356712464 & 1.154429082 & 0.251131658 & -0.296085033 & 1.119683519 & -0.296085033 & 1.119683519 \\
Work Life Balance & 0.962542812 & 0.078432166 & 12.27229675 & $1.58854 \mathrm{E}-21$ & 0.806896732 & 1.118188892 & 0.806896732 & 1.118188892 \\
\hline
\end{tabular}

Source: Survey Statistics

The results reveal that the WLB has a strong positive influence on work commitment. The $\mathrm{R}$ square value is $0.6058(60.58 \%)$ and as such, it can be concluded that, there are no evidence to reject the $\mathrm{H} 0$ at $95 \%$ confidence level. As such, this clearly state that the work life balance is one of the main factors affect to the employee commitment and quality work and family life balance enhance the working commitment.

\section{Conclusion}

More than $80 \%$ of respondents are female since women in the Sri Lankan culture represent majority of family daily workload. Since it is very important to 
maintain better work life among the nurses to obtain higher job commitment. Moreover, more than eighty present of nurses are engaging more than 50 hours per week. It means their work lord considerably high compare with the normal number of working hours per week.

Multiple regression model $\mathrm{R}^{2}$ value is 0.6358 . It means $63 \%$ of influence was represented by selected four variables namely job autonomy, financial encouragement, work stress and working environment. Moreover, working environment highly influence on work life balance of nurses. Since it is very important to improving favorable working environment to achieve high level of work life balance. On the other side, the second objective of this stud is aligns to measure the impact of work life balance on employee commitment. The results reveal that work life balance has a strong positive correlation with employees' commitment in the nursing profession. The policy makers in the health sector should come forward to make nurses life balanced with the hospital work as it has better outcome i.e. enhancement of commitment to work. This would be one of the critical success factors in terms of enhancing quality of service delivery of government hospitals. Having considered the output of the study, it is highly recommending the policy makers specially in the health sectors to make immediate attention to improve work life balance among nurses as one of the key players in the sector and it will definitely have positive externalities through establishing more committed pool of nurses in the government hospital chain which will lead to improve the quality of service delivery.

\section{Directions for Future Research}

This study was undertaken only using the sample selected from 3 government hospitals in Colombo area i.e. Colombo East Base Hospital, Colombo National Hospital and National Institute of Infectious Diseases Hospital (Fever Hospital) and in future study, it is highly recommended to do an extended analysis covering entire island in order to avoid homogeneous error which may be occurred due to limit the study for certain group who have similar characteristics. This sample was chosen from government hospitals and it would be more beneficial, if this research applied for private hospitals further. Findings of this research would be relevant to generalize to the total hospital population irrespective of limiting to the government sector, as there is a high tendency on increasing private sector healthcare in the Sri Lankan context. Further, researcher proposes to conduct same research for other positions in the health sector such as doctors and other supporting staff. This research was limited to examine four independent variables but future researchers should examine key other factors which may influence on work life balance base on different districts, age categories, Marital status and gender. 


\section{References}

Allen, I. (2006). Real-life strategies for work/life balance. Kingscliffe, N.S.W: Sea Change Publishing, 40(7), 64-65.

Ampem, D. A. (2018). The influence of work-life balance on employees' commitment among bankers in Accra, Ghana, 8(1), 47-55.

Azeem, S., Nadeem, A. (2014). The Influence of Work Life Balance and Job Satisfaction on Organizational Commitment of Healthcare Employees. International Journal of Human Resource Studies, 4(2), 18-24.

Balaji, R. (2014). Work Life Balance of Women Employees. International Journal of Innovative Research in Science, Engineering and Technology, 3(10), http://www.ijirset.com.

Beauregard, T. A. and Henry, L. C. (2009). Making the link between work-life balance practices and organizational performance. Human Resource Management Review, 19(1), 9-22.

Bruson, L., Warner-Smith, P., Brown. P. \& Fray, L. (2007). Managing the work-life roller-coaster: Private stress or public health issue. Social Science and Medicine, 65, 1142-1153.

Carlson, D. S., Kacmar, K. M., Grzywacz, J. G., and Tepper, B. J. (2013). WorkFamily Balance and Supervisor Appraised Citizenship Behavior: The Link of Positive Affect. Journal of Behavioral and Applied Management, 14(2), 87-106

Clark, S. C. (2001). Work cultures and work/family balance. Journal of Vocational Behavior, 58(3), 348-365

Clarke, S C (2000) Work/Family bothers theory for new theory of work life balance. Human Relations, 53(6), 747-770

Clutterbuck, D. (2003). Managing Work-life Balance: A Guide for HR in Achieving Organisational and Individual Change. London: Chartered Institute of Personnel and Development.

Cohen, A., \& Kirchmeyer, C. (2005). The cross- cultural study of the work/ non-work interface among Israeli nurses. Applied Psychology: An International Review, 54 (02), 40-121.

De Silva, B. S. S. and Rolls, C. (2010). Health care system and nursing in Sri Lanka: An ethnography study. Nursing \& Health Sciences, 12(1), 33-38.

Edwards, J., Rothbard, N. P. (2000). Mechanisms Linking Work and Family: Clarifying the Relationship Between Work and Family Constructs. The Academy of Management Review, 25(1), 178.

Fereday, J., \& Oster, C. (2010). Managing a work-life balance: The experiences of midwives working in a group practice setting. Midwifery, 26, 311-318. 
Fisher, C. D. (2000). Mood and emotions while working: Missing pieces of job satisfaction? Journal of Organizational Behavior, 21(2), 185-202.

Gebremichael, H., Rao, B. V. P. (2013). Job satisfaction and organizational commitment between academic staff and supporting staff: Wolaita Sodo University-Ethiopia as a case. East Journal of Psychology and Business, 11(1), $11-32$

Grzywacz, et.al (2006). Toward a theory of Work-family facilitation. Paper presented at the 32nd annual Theory Construction and Research Methodology Workshop of the Persons, National Council on Family Relations, Houston, TX.

Greenblatt, E. (2002). Work Life Balance: Wisdom or Whining. Organizational Dynamics, 31(2), 177-193.

Greenhaus, J. H., Collins, K.M. \& Shaw, JD 2003, 'The relation between work-family balance and quality of life'. Journal of Vocational Behavior, 63, 510-531.

Judge, T. \& Colquitt, J. (2004). Organizational justice and stress: The mediating role of work- family conflict. Journal of Applied Psychology, 89 (3), 395-404.

Kang, D., Rice, M., Park, N. Turner-Henson, A. \& Downs, C. (2010). Stress and inflammation: 94 Porter, S. \& Ayman, R. (2010). Work flexibility as a mediator of the relationship between work- family conflict and intention to quit. Journal of Management \& Organization, 16, 411-424

Kumaraswamy, M., Ashwini, S. (2015). Challenges in Work Life Balance of Married Working Women: A Study in Selected Indian Banks in Karnataka, 4(4), 22-42.

Moorman. R.H. (1995). The Influence of Cognitive and Affective Based Job Satisfaction Measures on the Relationship Between Satisfaction and Organizational Citizenship Behavior. Journal of Organizational behavior, 16(1), 127-142.

Nguru, R. M., Gichuhi, D. (2018). Influence of work Life Balance on Employee Commitment in Parastatals: A Case study of National Hospital Insurance Fund in Nakuru, Kenya. International Journal of Economics, Commerce and Management United Kingdom, 6(5), 378-407.

O'Connell, P. J., Russell, H., Williams, J. and Blackwell, S. (2010). The Changing Workplace A Survey of Employees' Views and Experiences, National Centre for Partnership and Performance and Economic and Social Research Institute.

Porter, S., Ayman, R. (2010). Work flexibility as a mediator of the relationship between work-family conflict and intention to quit, Journal of Management \& Organization 16(3):411-424.

Porter, L. W. and Lawler, E. E. (1968). What job attitudes tell about motivation? Harvard Business Review, 46(1), 118-126. 
Raziq, A., Maulabakhsh, R. (2014). The Impact of Working Environment on Job Satisfaction, Procedia Economics and Finance. Second Global Conference on Business, Economics, Management and Tourism, 30-31 October 2014, Prague, Czech Republic.

Sakthivel, D. \& Jayakrishnan, J. (2012). Work Life Balance and Organizational Commitment for Nurses. Asian Journal of Business and Management Sciences, 2 (5), 01-06.

Sakthivel, R. \& Kamalanabhan. (2011). Work life balance reflections on employee satisfaction. Serbian Journal of Management, 6(1), 85-96.

Scherer,S.(2009).The Social Consequences of Insecure Jobs. Social Indicators Research, 93(3), 527-547

Scholarios, D., \& Marks, A. (2006). Worklife balance and the software worker. Human Resource Management Journal, 14(2), 54-74.

Spector, P.E. Job satisfaction: Application, assessment, causes and consequences, Thousand Oaks, CA, Sage Publications, Inc; 1997. Psychology Faculty Publications. 554. https://scholarcommons.usf.edu/psy_facpub/554.

Suguna, G., Franco, C. E. (2017). A Study on Work Life Balance of Nursing Staff working in Private Hospitals, International Journal of Research Granthaalayah, 5(8:SE), 72-75. https://doi.org/10.5281/zenodo.888017.

Suresh, D. (2013). 'Quality of Nursing Work Life among nurses working in selected government and private hospitals in Thiruvananthapuram.

Tayfun, A., Catir, O. (2014). An Empirical Study into the Relationship between Work Life Balance and Organizational Commitment. The Journal of Industrial Relations and Human Resources, 16(1), 20-37, DOI: 10.4026/13032860.2014.0245.

Tennant, C. (2001). Work-related stress and depressive disorders. Journal of Psychosomatic Research, 697-704.

Tennant, G. P., Sperry, L. (2003). Work-Family Balance: Counseling Strategies to Optimize Health. The Family Journal 11(4), 404-408

Wayman, J. C., Jimerson, J. B. \& Vincent, C., Organizational considerations in establishing the Data-Informed District. International Journal of Research, Policy and Practice, 23(2), 159-178.

Young, M. B. (1999). Work-Family Backlash: Begging the Question, What's Fair? Annals Am. Acad. Political Soc. Sci., 562(1), 32-46. 